\title{
Representation of the spatial association between salinity and water chemical properties in Al-Hassa Oasis
}

\author{
Ibrahim Alhawas, Abdalhaleem A. Hassaballa* \\ (Department of Environment \& Agricultural Natural Resources, College of Agricultural and Food Sciences, King Faisal University, KSA)
}

\begin{abstract}
With poor irrigation water quality, cultivation difficulties are certainly expected to rise. This will cause a severe reduction in crops yield unless a strong strategy is followed to control and sustain high yielding capacity under particular circumstances. Water salinity presented in the form of water electrical conductivity (EC), has been presented in this study as one of the parameters that significantly participated in decreasing the quality of irrigation water in Al-Hassa oasis at Kingdom of Saudi Arabia. The sharing factors in quantifying water EC and its distribution spacewise has been examined by applying the frequency ratio (FR) technique (spatial autocorrelation) between salinity status and water measured elements, specifically, chlorine $\left(\mathrm{Cl}^{-}\right)$, sodium $\left(\mathrm{Na}^{+}\right)$, calcium $\left(\mathrm{Ca}^{2+}\right)$, potassium $\left(\mathrm{K}^{+}\right)$and magnesium $\left(\mathrm{Mg}^{2+}\right)$. A threshold salinity value of $(\mathrm{EC} \geq$ $2.0 \mathrm{dS} / \mathrm{m}$ ) was identified as a break-line for classifying the well-water sources that non-valid for irrigating vegetables grown in the area. A statistical correlation among the examined parameters and EC was conducted using the statistical package for social sciences (SPSS), and compared to the applied FR technique. A dosage of $\mathrm{Cl}^{-}$in irrigation water was observed to be the most significant candidate that raised EC, proved by an $R^{2}$ of $63 \%$. However, the FR technique has shown the validity in analyzing the spatial distribution of water measured variables; in addition to nominating the variable that had the higher association portion, which was assessed to be $\mathrm{Na}^{+}$, followed by $\mathrm{Cl}^{-}$with prediction rates of 4.22 and 3.22, respectively.
\end{abstract}

Keywords: statistical correlation, GIS, water salinity, Al-Hassa, prediction rate

DOI: $10.25165 /$ j.ijabe.20201302.5298

Citation: Alhawas I, Hassaballa A A. Representation of the spatial association between salinity and water chemical properties in Al-Hassa Oasis. Int J Agric \& Biol Eng, 2020; 13(2): 168-174.

\section{Introduction}

Water salinity is presently considered as a major global threat to agriculture, which is originated mainly from pesticide and fertilization activities over arable lands. Globally, total annual losses in farm products because of salinization exceeds $\$ 12$ billion $^{[1]}$. Salinity is a multivariate phenomenon, it could be osmotic, in which the high concentrations of $\mathrm{NaCl}$ suppresses water uptake, causing slow development and leading to death of sensitive parts of the plant ${ }^{[2]}$.

The over-abundance of salinity in irrigation water can cause critical morphological changes/shortness in the plant development span. Demonstrated by different reactions, morphological parameters such as plant height and leaf production in the vegetative period of plant growth are susceptible to high salinity of irrigation water. Meanwhile, not all plants react to salinity in a comparable way; some crops could yield worthy at even a lot more successive water salinity than others. The capacity of the crop to adapt with salinity is very valuable. There is a wide range in salinity tolerance of agricultural crops, which permits more utilization of moderately-saline water. It also significantly increases the adequate range of water salinity (EC) considered for irrigation. The relative salinity tolerance in most crops were recognized to provide common salt-tolerance guidelines. Such

Received date: 2019-07-18 Accepted date: 2020-02-06

Biographies: Ibrahim Alhawas, PhD, Professor, research interests: Origin of clay minerals and service chemistry, Email: ihawas@kfu.edu.sa.

*Corresponding author: Abdalhaleem Abdalla Hassaballa, PhD, Assistant Professor, research interests: precision agriculture. P.O. Box 400, Al-Hassa 31982, Saudi Arabia. Tel: +966135895896, Cell: +966549522886, Email: ahassaballa@kfu.edu.sa, guidelines were taken into account when presenting the levels of 'constraint on use' in the guidelines.

Upon the states of utilization including crop, climate, soil, irrigation technique and the management practices, the reasonableness of a saline water for irrigation is still needy, and water quality characterizations are not exhorted for evaluating water appropriateness for irrigation. However, to identify the degrees of water salinity for which these rules are established, it is helpful to give a classification plan $^{[3]}$. Such a classification is presented in Table 1 as far as total salt fixation, which is the significant quality factor that commonly constrains the use of saline waters for crops yielding. Generally utilized irrigation systems whose water salinity exceeds $2 \mathrm{dS} / \mathrm{m}$ in EC were rarely found ${ }^{[3]}$. In fact, exceptionally tolerant plants can be effectively survived with waters that surpasses $10 \mathrm{dS} / \mathrm{m}$ in EC.

Table 1 Saline water classification as per food and agriculture organization's (FAO) recommendation $^{[3]}$

\begin{tabular}{cccc}
\hline Water class & $\begin{array}{c}\text { Electrical } \\
\text { conductivity/dS } \cdot \mathrm{m}^{-1}\end{array}$ & $\begin{array}{c}\text { Salt concentration } \\
/ \mathrm{mg}^{-1}\end{array}$ & Type of water \\
\hline Non-saline & $<0.7$ & $<500$ & $\begin{array}{c}\text { Drinking and irrigation } \\
\text { water }\end{array}$ \\
$\begin{array}{c}\text { Slightly saline } \\
\text { Moderately } \\
\text { saline }\end{array}$ & $0.7-2$ & $500-1500$ & $\begin{array}{c}\text { Irrigation water } \\
\text { Primary drainage water } \\
\text { and groundwater }\end{array}$ \\
$\begin{array}{c}\text { Highly saline } \\
\begin{array}{c}\text { Very Highly } \\
\text { saline }\end{array}\end{array}$ & $10-25$ & $7000-15000$ & $\begin{array}{c}\text { Secondary drainage } \\
\text { water and groundwater }\end{array}$ \\
Brine & $25-45$ & $15000-35000$ & Very saline groundwater \\
\hline
\end{tabular}

Cations such as $\mathrm{Na}^{+}, \mathrm{K}^{+}, \mathrm{Mg}^{2+}$, and $\mathrm{Ca}^{2+}$ play a significant role in plant growth. They are essential macronutrients for plant and have numerous functions, for instance, nourishment, activation of 
many enzymes as well as securing the electrical gradients in cell membranes. They are also considered essential for osmotic regulation in plants; in addition to their responsibility of balancing water transport to the plant, especially $\mathrm{K}^{+}$ion $^{[4]}$. However, it has been demonstrated that cations concentration $\left(\mathrm{Ca}^{2+}\right.$ as highest; followed by $\mathrm{Mg}^{2+}, \mathrm{Na}^{+}$, and $\mathrm{K}^{+}$) are the most triggering factors in water EC increase. When low-moderate salinity affects plant, it might metabolize ordinarily and does not indicate effect of damage. In any case, more energy is needed to keep up ordinary metabolism need $^{[5]}$, which may cause decrease in development and yield ${ }^{[6]}$. In majority of crops, decrease in yield can be important even before foliar damage appears ${ }^{[7]}$. in fact, salinity can hinder plant development through osmotic impacts, nutrient uptake imbalance, toxicity of ions, or poisonous quality of particles, supplement take-up lopsidedness, or even a combination of the two of them ${ }^{[8,9]}$

\section{Spatial assessment of salinity distribution}

Geographic information system (GIS) has become a very efficient tool nowadays for data treatment and manipulation, especially for statistical measures. Many techniques are applied for identifying the zonation of environmental events (i.e. landslide, flood, salinization, etc.). Generally, they can be grouped into three types namely, qualitative, semi-quantitative and quantitative approaches. For qualitative approaches, scores are mostly assigned to factors based on professional knowledge. In the semi quantitative approaches, weights are assumed and ranking on the basis of logical tools are made, such as the analytical hierarchy process (AHP), fuzzy logic and weighted linear combination (WLC). The quantitative approaches, are statistical methods that drive the inventory of the environmental events and consider their factor's associations with event inventory. On the base of the event, densities represented in factor classes, weights/ratings are mathematically calculated. This can additionally be divided into bivariate and multivariate approaches ${ }^{[10-13]}$.

Bivariate approaches quantitatively calculate the susceptibility of events occurrence through computing each individual class's weight of the event factors. Generally, the analysis of bivariate statistics is applied to depict the overlay of the environmental event's inventory map with maps of the influencing parameters of the event, in order to rank the corresponding classes according to their participation in event formation ${ }^{[14,15]}$. One of the most popular bivariate approaches is the frequency ratio $(\mathrm{FR})^{[16]}$, which can have greater rigors comparing to other bivariate techniques ${ }^{[15,17]}$. Similar studies ${ }^{[18]}$ have been conducted and succeeded in mapping the tendency by examining the independent and dependent factors and their contribution using the bivariate statistics for similar events (landslide, floods, contaminant diffusion, etc). However, the use of such techniques in mapping well-water salinity based on water chemical properties was very limited. Thus, this study aimed at applying the frequency ratio technique (FR) in order to: (a) produce a quantitative assessment of the water EC through zoning and quantifying the associated chemical parameters with their subclasses; (b) examine the feasibility of using FR technique as a predictor for water salinity evolution at wells that are affected by variability in applied chemicals; and (c) assess the quantitative association and the spatial distribution of the EC controlling factors.

\section{Materials and methods}

\subsection{Study area}

Al Hassa oasis is located at nearly $70 \mathrm{~km}$ inland of the coast of
Arabian Gulf. The oasis covers an approximated area of $20000 \mathrm{hm}^{2}$; forming an L-shaped (Figure 1), which is in fact composed of two discrete oases ${ }^{[19]}$. The basic water sources comprise the Neogene groundwater aquifer, in addition to some springs that are circulated across the are ${ }^{[20]}$. Geologically, this area is a portion of the Arabian Shelf where the Mesozoic and Cenozoic series of strata incline gently about $1.0 \mathrm{~m} / \mathrm{km}$ towards the east ${ }^{[21]}$, and is mainly covered by the sand dunes of Al-Jafurah. In the west, the land is raised exceptionally to an altitude of $250 \mathrm{~m}$ above sea level due to the steep scarp of al-Ghawar, superimposing older formations ${ }^{[22]}$. The geographical aspects in addition to the hydrology of the area are intensely influenced by the Ghawar structure made by Cretaceous and Lower Tertiary tectonics ${ }^{[21]}$. Wakuti ${ }^{[23]}$ recorded 336 wells within the area of the oasis, beside 162 springs (including 35 large springs). Water depths of some of the wells range between 100-180 $\mathrm{m}$ and a depth limit reached $250 \mathrm{~m}$.

The study area, which is part of Al-Hassa old oasis, were situated within the province covering an area of about $185 \mathrm{~km}^{2}$, spanned between longitudes of $49^{\circ} 35^{\prime}-49^{\circ} 45^{\prime} \mathrm{E}$ and latitudes $25^{\circ} 20^{\prime}-25^{\circ} 30^{\prime} \mathrm{N}$ (Figure 1), at an elevation range of 130 to $160 \mathrm{~m}^{[24]}$ Within the study area layout, 46 wells used for irrigation have been identified and assigned for water quality measurements and modeling.

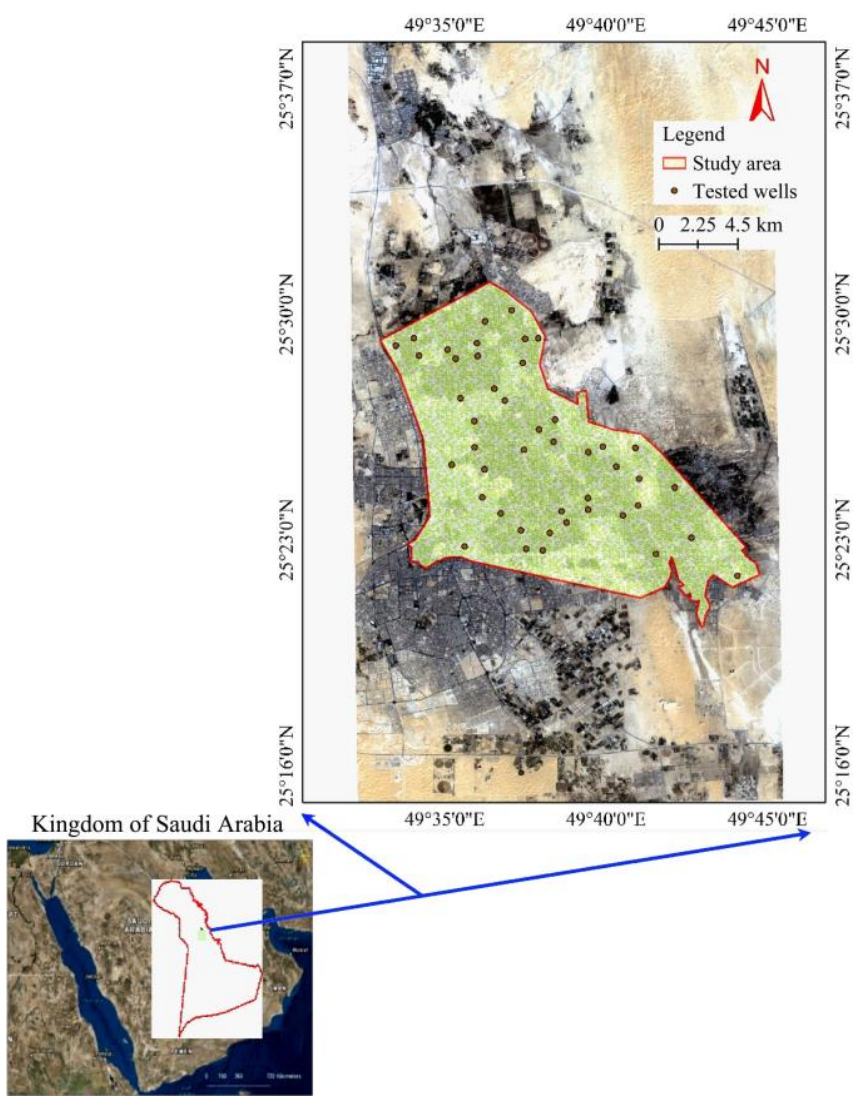

Figure 1 The study area location and wells distribution

\subsection{Data collection and analysis}

\subsubsection{Field data}

The field experiment was set to contain one time assortment of water samples from 46 wells that randomly distributed in the study area. The random selection of the testing wells was achieved with an aim to represent nearly the full area of the study. Global positioning system (GPS) device (Trimble GeoXH) was used for water samples collection, as well as for allocating the wells position to resultant the analysis maps. 
The collected water samples were analyzed for 6 types of parameters, namely; chlorine $\left(\mathrm{Cl}^{-}\right)$; sodium $\left(\mathrm{Na}^{+}\right)$; magnesium $\left(\mathrm{Mg}^{2+}\right)$; calcium $\left(\mathrm{Ca}^{2+}\right)$; potassium $\left(\mathrm{K}^{+}\right)$; and water salinity measured in the form of electric conductivity (EC). For all analyzed samples, 3 replicates were applied, then an average value for each sample was calculated for the analysis. All applied laboratory measurements, calibrations and analysis were achieved at King Faisal University's central lab. The analyzed water chemical properties were assessed in milligrams $(\mathrm{mg})$ weight per litter (L) of water while, the water salinity measurement was assessed using conductivity unis, which is deciSiemens per meter $(\mathrm{dS} / \mathrm{m})$.

\subsubsection{Statistics of the collected data}

The collected water samples throughout study area were statistically examined to address any correspondence or variability and their zonation within the field. From the descriptive statistics in Table 2, it can be noticed that the coefficient of variation $(\mathrm{Cv})$ calculated for the specified data implies significant variabilities for all water chemical parameters value.

Table 2 Statistical description of water chemical properties and salinity

\begin{tabular}{|c|c|c|c|c|c|c|c|}
\hline \multirow{2}{*}{ Parameter } & \multirow{2}{*}{$\begin{array}{c}\mathrm{N} \\
\text { Statistic }\end{array}$} & \multirow{2}{*}{$\begin{array}{c}\text { Minimum } \\
\text { Statistic }\end{array}$} & \multirow{2}{*}{$\begin{array}{c}\text { Maximum } \\
\text { Statistic }\end{array}$} & \multicolumn{2}{|c|}{ Mean } & \multirow{2}{*}{$\begin{array}{c}\begin{array}{c}\text { Std. } \\
\text { Deviation }\end{array} \\
\text { Statistic }\end{array}$} & \multirow{2}{*}{$\mathrm{Cv}$} \\
\hline & & & & Statistic & $\begin{array}{l}\text { Std. } \\
\text { Error }\end{array}$ & & \\
\hline $\mathrm{Cl}$ & 46 & 1.8 & 9.8 & 4.43 & 0.39 & 1.97 & 0.44 \\
\hline $\mathrm{Na}$ & 46 & 24.0 & 275.5 & 113.46 & 15.50 & 77.52 & 0.68 \\
\hline $\mathrm{Mg}$ & 46 & 1.6 & 29.5 & 11.38 & 1.47 & 7.37 & 0.65 \\
\hline $\mathrm{Ca}$ & 46 & 2.1 & 20.6 & 7.24 & 0.99 & 4.98 & 0.68 \\
\hline $\mathrm{K}$ & 46 & 1.0 & 25.0 & 10.58 & 1.23 & 6.14 & 0.58 \\
\hline $\mathrm{EC}$ & 46 & 1.6 & 9.7 & 4.58 & 0.44 & 2.21 & 0.48 \\
\hline
\end{tabular}

The study intended to carry out a spatial auto-correlation process between the given water chemical parameters presented as independent variables and water EC, representing a dependent variable. Initially, linear regression and correlation processes were adopted to investigate the statistical relationship between the analyzed parameters, in which the statistical package for social sciences (SPSS) software program was used. The bivariate statistics was also applied for the acquired data in order to assess the degree of association of each independent variable's classes in quantifying the salinity value. On the other hand, spatial interpolation was used in order to depict the general trend, spatial distribution as well as the general orientation of the analyzed water properties throughout the study area. ArcGIS 10.3 software program was used for the resultant interpolation mapping in which "the kriging interpolation" tool of the software was used for maps generation. Hence, the study applied the frequency ratio method to observe the association of water chemical properties (as independent factors) with the zonation of salinity (dependent).

\subsubsection{Setting variables}

Both associating variables (independents/predictors) and the salinity (dependent) that produced in maps form were reclassified into three classes to rank their values (high, medium and low) with a 'natural breaks' classification range at ESRI ArcMAP software program. A threshold value of water salinity equals to $2 \mathrm{dS} / \mathrm{m}$ was identified among the 46 samples. It has been found that 25 points (wells) among the total observation wells have a water salinity of $2 \mathrm{dS} / \mathrm{m}$ or higher (moderate saline and higher as per food and agriculture organization (FAO) classification-Table 1). Only wells with salinity value $\geq 2.0 \mathrm{dS} / \mathrm{m}$ were considered for the frequency ratio analysis, considering the difficulty that associated with applying water with such salinity for irrigating all types of vegetable that are being grown beneath the dates palm canopy in the oasis. The randomly distributed 25 wells that represent the dependent variables, were then subjected to the spatial correlation process, and applied as discrete points with one rank. The later step was achieved in order to prepare for the analysis of identifying the wells' percentage that associated with each class (value range) in the independent variables $\left(\mathrm{Cl}^{-}, \mathrm{Na}^{+}, \mathrm{Ca}^{2+}, \mathrm{K}^{+}\right.$and $\left.\mathrm{Mg}^{2+}\right)$.

The frequency ratio (FR) along with the relative frequency (RF) and the prediction rate (PR) factors were estimated for every factor according to the rank of the sub-classes. Furthermore, a supportive comparison process (pairwise comparison) was also conducted along with the produced PR to correlate the given factors and compare their status result with the PR. The FR can be explained as the vulnerability of every sub-category that exist to the percentage (weight) of the category for independent factors, as stated in Equation (1). The relative frequency from the other side, denotes the weight of every FR to the entire FR in the classes of certain factor (Equation (2)). Thus, the PR is applied to measure the interrelationships among the independent factors, which is clarified by Equation (3) ${ }^{[25]}$.

$$
\begin{gathered}
F R=\frac{\% \text { target occurence in each subcategory }}{\% \text { category of an independent factor }} \\
=\frac{(\text { points in factor } / \text { total points })}{(\text { factor class area } / \text { total area })} \\
F R=\frac{\text { factor class } F R}{\sum \text { factor Classes } F R} \\
F R=\left(R F_{\max }-R F_{\min }\right) /\left(R F_{\max }-R F_{\min }\right) M i n
\end{gathered}
$$

where, $F R$ is frequency ratio; $R F$ is relative frequency (an index reveals the spatial association among the spatial factors and the targets); $P R$ is prediction rate.

3.2.4 Pairwise comparison (PW)

Pairwise comparison is whichever method that comparing objects in pairs to examine which one is ideal, or has a bigger amount of measurable property, or whether two objects are matching or not. The pairwise comparison technique is applied in the scientific study of preferences, voting classifications, social and public choice attitudes, sometimes referred to as paired comparison.

The PW comparison matrix was conducted in the study, in order to examine the accuracy of the generated prediction rates of the independent variables. The pre-assessed prediction rates (PR) were organized in a table, in vertical and horizontal manners. Hence, factors have been contractively weighed to examine the interrelationship among each two factors.

\section{Results and discussion}

\subsection{Variables correlation}

Table 3 showed the resultant correlation between the extracted variables, revealing a relatively high relationship between water $\mathrm{Cl}^{-}$ of the distributed samples and the respective EC with a correlation coefficient of 0.63 . This comes on line with several studies that worked on examining the $\mathrm{Cl}^{-}$-EC relationships and intended to estimate the concentration of chloride ions as a function of the electrical conductivity of water ${ }^{[26,27]}$. A study on concentration of $\mathrm{Cl}$ and EC for several salty waters in central part of Iran stated by Hajrasuliha ${ }^{[28]}$ suggested an occurrence likelihood of a generalized empirical association among these two parameters. Other investigations by $\mathrm{Ursin}^{[29]}$ and $\operatorname{Volker}^{[30]}$ reported that the 
consistent predictions of the solute conveyance within flow schemes have principally based on the $\mathrm{Cl}^{-}$capacities. The tightness indicator of EC with respect to the other parameters has also shown significant correlations, especially for $\mathrm{K}^{+}$and $\mathrm{Ca}^{2+}$ where the coefficient of correlation was measured to be 0.53 and 0.51 , respectively.

Table 3 Correlation between the extracted properties of irrigation water

\begin{tabular}{|c|c|c|c|c|c|c|c|}
\hline & & $\mathrm{Cl}$ & $\mathrm{Na}$ & $\mathrm{Mg}$ & $\mathrm{Ca}$ & $\mathrm{K}$ & $\mathrm{EC}$ \\
\hline \multirow{3}{*}{$\mathrm{Cl}$} & Pearson correlation & 1 & 0.131 & $0.542^{* * *}$ & $0.856^{* *}$ & 0.157 & $0.626^{* *}$ \\
\hline & Sig. (2-tailed) & & 0.531 & 0.005 & 0.000 & 0.454 & 0.001 \\
\hline & $\mathrm{N}$ & 46 & 46 & 46 & 46 & 46 & 46 \\
\hline \multirow{3}{*}{$\mathrm{Na}$} & Pearson correlation & 0.131 & 1 & -0.139 & 0.037 & 0.360 & $0.407^{*}$ \\
\hline & Sig. (2-tailed) & 0.531 & & 0.507 & 0.861 & 0.077 & 0.043 \\
\hline & $\mathrm{N}$ & 46 & 46 & 46 & 46 & 46 & 46 \\
\hline \multirow{3}{*}{$\mathrm{Mg}$} & Pearson correlation & $0.542^{* *}$ & -0.139 & 1 & $0.710^{* *}$ & 0.234 & 0.031 \\
\hline & Sig. (2-tailed) & 0.005 & 0.507 & & 0.000 & 0.260 & 0.885 \\
\hline & $\mathrm{N}$ & 46 & 46 & 46 & 46 & 46 & 46 \\
\hline \multirow{3}{*}{$\mathrm{Ca}$} & Pearson correlation & $0.856^{* *}$ & 0.037 & $0.710^{* *}$ & 1 & 0.380 & $0.510^{* *}$ \\
\hline & Sig. (2-tailed) & 0.000 & 0.861 & 0.000 & & 0.061 & 0.009 \\
\hline & $\mathrm{N}$ & 46 & 46 & 46 & 46 & 46 & 46 \\
\hline \multirow{3}{*}{$\mathrm{K}$} & Pearson correlation & 0.157 & 0.360 & 0.234 & 0.380 & 1 & $0.531^{* *}$ \\
\hline & Sig. (2-tailed) & 0.454 & 0.077 & 0.260 & 0.061 & & 0.006 \\
\hline & $\mathrm{N}$ & 46 & 46 & 46 & 46 & 46 & 46 \\
\hline \multirow{3}{*}{$\mathrm{EC}$} & Pearson correlation & $0.626^{* *}$ & $0.407^{*}$ & 0.031 & $0.510^{* *}$ & $0.531^{* *}$ & 1 \\
\hline & Sig. (2-tailed) & 0.001 & 0.043 & 0.885 & 0.009 & 0.006 & \\
\hline & $\mathrm{N}$ & 46 & 46 & 46 & 46 & 46 & 46 \\
\hline
\end{tabular}

Note: **. Correlation is significant at the 0.01 level (2-tailed). *. Correlation is significant at the 0.05 level (2-tailed).

The linear regression that was conducted between the measured variables $\left(\mathrm{Cl}^{-}, \mathrm{Na}^{+}, \mathrm{Ca}^{2+}, \mathrm{Mg}^{2+}\right.$ and $\left.\mathrm{K}^{+}\right)$has revealed noticeable indications as predictors of EC; producing $R^{2}$ of 0.79 at a significance level of 0.01 (Table 4). This substantially assured the positive relationships between water EC (on the one hand) and the extracted parameters (on the other hand), supported by the applied analysis of variance (ANOVA) test at significance of $\mathrm{P}$ value $<0.0001$ for the predictors (Table 4). Away from the individual contribution of the sub-classes of the parameters, the results implied that all examined parameters had significant quantitative association with EC. However, the focal analysis was to examine the correlations that rose among the measured values and EC, so as to assess the most vulnerable class (within a parameter's value) that helps in predicting EC.

Table 4 Summary of the linear regression between EC and the extracted variables

\begin{tabular}{|c|c|c|c|c|c|c|c|c|}
\hline \multirow[b]{2}{*}{ Model } & \multirow[b]{2}{*}{$\mathrm{R}$} & \multirow{2}{*}{$\begin{array}{c}\mathrm{R} \\
\text { square }\end{array}$} & \multirow{2}{*}{$\begin{array}{l}\text { Adjusted } \\
\text { R square }\end{array}$} & \multirow{2}{*}{$\begin{array}{l}\text { Std. } \\
\text { error of } \\
\text { the } \\
\text { estimate }\end{array}$} & \multicolumn{4}{|c|}{ Change Statistics } \\
\hline & & & & & $\begin{array}{l}\text { R square } \\
\text { change }\end{array}$ & F change & df1 df2 & $\begin{array}{l}\text { Sig. F } \\
\text { change }\end{array}$ \\
\hline 1 & $0.890^{\mathrm{a}}$ & 0.793 & 0.738 & 1.12922 & 0.793 & 14.517 & 19 & 0.000 \\
\hline \multicolumn{9}{|c|}{$\begin{array}{l}\text { a. Predictors: (Constant), } \mathrm{K}^{+}, \mathrm{Cl}^{-}, \mathrm{Na}^{+}, \mathrm{Mg}^{2+}, \mathrm{Ca}^{2+} \\
\text { b. Dependent Variable: EC }\end{array}$} \\
\hline \multicolumn{9}{|c|}{ ANOVA } \\
\hline & Model & & $m$ of squares & df & Mean & square & $\mathrm{F}$ & Sig. \\
\hline \multirow{3}{*}{1} & Regressi & & 92.552 & 5 & & .510 & 14.517 & $0.000^{\mathrm{b}}$ \\
\hline & Residua & & 24.227 & 19 & & 275 & & \\
\hline & Total & & 116.780 & 24 & & & & \\
\hline
\end{tabular}

a. Dependent Variable: EC

b. Predictors: (Constant), K, $\mathrm{Cl}, \mathrm{Na}, \mathrm{Mg}, \mathrm{Ca}$

The spatial distribution of the water salinity in addition to the dissolved matters was shown in Figure 2, where 3 value ranks (High, medium and low) were presented for each parameter. It can be interpreted basically that most of the variables with high concentrations of measured value (i.e. $\mathrm{EC}, \mathrm{Na}^{+}, \mathrm{Ca}^{2+}$ and $\mathrm{K}^{+}$) were located in the middle of the area. Meanwhile, the chlorine has uniquely shown a lateral distribution of its high value, extending along the eastern side of the study area. There is no exact justification for the concentrations variety in water elements because the area is occupied by several farms that belong to individuals and no obligatory fertilization policy was applied to control the cultivation process. The spatial distribution of the extracted $\mathrm{Mg}$ did not show a specific trend that follows the EC distribution.

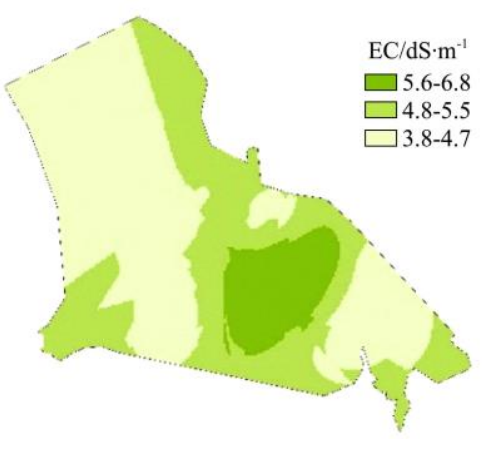

a.

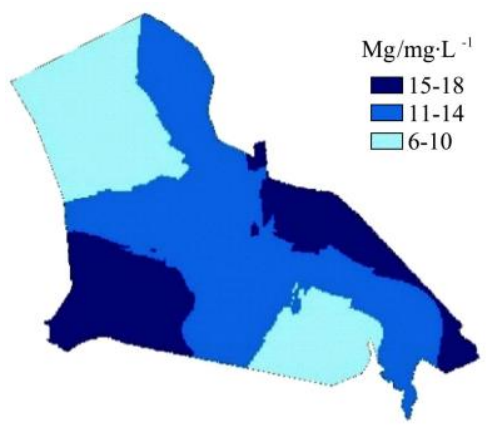

d.

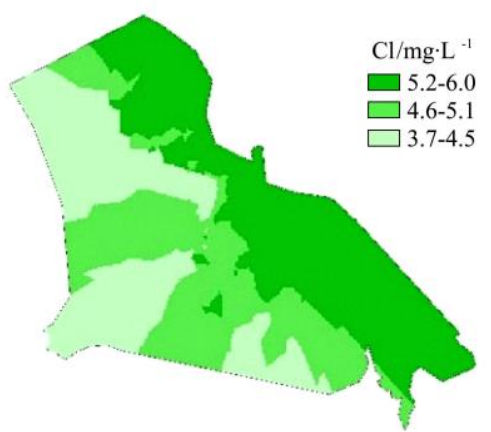

b.

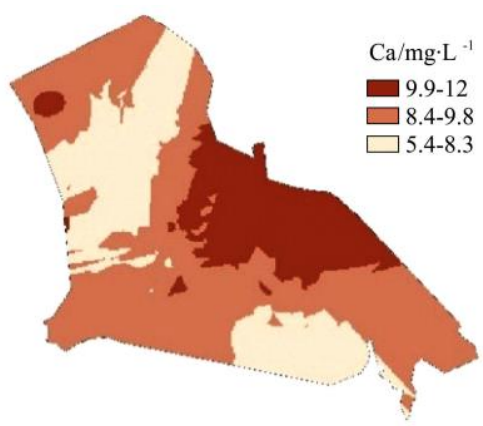

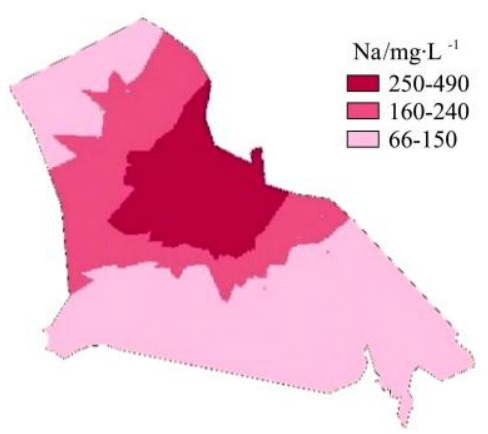

c.

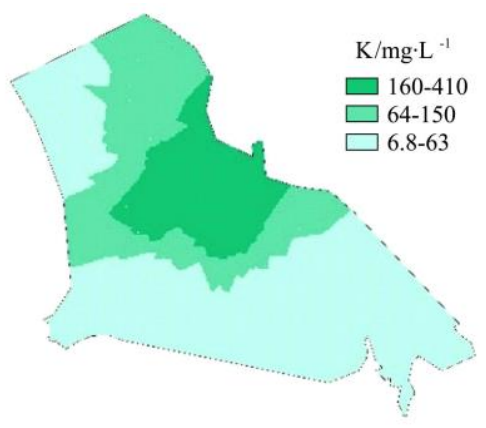

Figure 2 Spatial distribution of the water salinity and the dissolved matters 


\subsection{Prediction rate assessment}

The application of FR method has been concluded for the estimation of PR of variable's sub-classes that have associated in the generation of the zone of $2.0 \mathrm{dS} / \mathrm{m}$ and above. The process of $\mathrm{PR}$ calculation in turn involved the calculation of RF for every subclass of the factors that associated in the zonation of the moderately high EC (of $2.0 \mathrm{dS} / \mathrm{m}$ and above). This was achieved in order to compute the relative involvement of independent factors in predicting the assessed EC threshold (dependent factor). Table 5 shows the number of wells with the threshold EC value that spatially correlate the independent factor maps, carried out by the ArcMAP (tabulate area) tool. Each class points were then calculated as percentage. Ground areas covered by classes were correspondingly calculated by summing every pixel's area of a class; and the fraction of every class area was identified. A ratio between every class points (wells) and class area ratio was used to create the RF as a relative ratio to the entire ratios.

Table 5 Estimating the relative frequency for the variables

\begin{tabular}{|c|c|c|c|c|c|c|c|}
\hline Factor & $\begin{array}{l}\text { Factor classes } \\
\qquad / \mathrm{mg} \cdot \mathrm{L}^{-1}\end{array}$ & $\begin{array}{l}\text { No. of } \\
\text { points }\end{array}$ & $\begin{array}{l}\% \text { of } \\
\text { points }\end{array}$ & $\begin{array}{c}\text { Class } \\
\text { area }\end{array}$ & $\begin{array}{c}\% \text { of } \\
\text { class area }\end{array}$ & Ratio & $\mathrm{RF}$ \\
\hline \multirow{4}{*}{$\mathrm{Cl}^{-}$} & $3.7-4.5$ & 0.000002 & 18.18 & 9698 & 29.83 & 0.61 & 0.21 \\
\hline & $4.6-5.1$ & 0.000005 & 45.45 & 12762 & 39.25 & 1.16 & 0.39 \\
\hline & $5.2-6.0$ & 0.000004 & 36.36 & 10053 & 30.92 & 1.18 & 0.40 \\
\hline & Sum & 0.000011 & 100.00 & 32513 & 100.00 & 2.94 & 1.00 \\
\hline \multirow{4}{*}{$\mathrm{Na}^{+}$} & $66-150$ & 0.000007 & 58.33 & 17343 & 53.34 & 1.09 & 0.40 \\
\hline & $160-240$ & 0.000004 & 33.33 & 9381 & 28.85 & 1.16 & 0.43 \\
\hline & $250-490$ & 0.000001 & 8.33 & 5789 & 17.81 & 0.47 & 0.17 \\
\hline & Sum & 0.000012 & 100.00 & 32513 & 100.00 & 2.72 & 1.00 \\
\hline \multirow{4}{*}{$\mathrm{Mg}^{2+}$} & $6.0-10.0$ & 0.000004 & 36.36 & 9803 & 30.15 & 1.21 & 0.41 \\
\hline & $11-14$ & 0.000005 & 45.45 & 15162 & 46.63 & 0.97 & 0.33 \\
\hline & $15-18$ & 0.000002 & 18.18 & 7548 & 23.22 & 0.78 & 0.26 \\
\hline & Sum & 0.000011 & 100.00 & 32513 & 100.00 & 2.96 & 1.00 \\
\hline \multirow{4}{*}{$\mathrm{Ca}^{2+}$} & $5.4-8.3$ & 0.000003 & 27.27 & 9305 & 28.62 & 0.95 & 0.33 \\
\hline & $8.4-9.8$ & 0.000006 & 54.55 & 16566 & 50.95 & 1.07 & 0.37 \\
\hline & $9.9-12$ & 0.000002 & 18.18 & 6642 & 20.43 & 0.89 & 0.31 \\
\hline & Sum & 0.000011 & 100.00 & 32513 & 100.00 & 2.91 & 1.00 \\
\hline \multirow{4}{*}{$\mathrm{K}^{+}$} & $6.8-63$ & 0.000008 & 72.73 & 18347 & 56.43 & 1.29 & 0.57 \\
\hline & $64-150$ & 0.000003 & 27.27 & 9035 & 27.79 & 0.98 & 0.43 \\
\hline & $160-410$ & 0 & 0.00 & 5131 & 15.78 & 0.00 & 0.00 \\
\hline & Sum & 0.000011 & 100.00 & 32513 & 100.00 & 2.27 & 1.00 \\
\hline
\end{tabular}

Resultant RF from Table 5 obviously reveals that sub-classes which had the highest relative association weights towards EC threshold correlation were namely; $\mathrm{Cl}^{-}$sub-class $(5.2-6.0 \mathrm{mg} / \mathrm{L})$, $\mathrm{Na}^{+}(160-240 \mathrm{mg} / \mathrm{L}), \mathrm{Mg}^{2+}(6.0-10.0 \mathrm{mg} / \mathrm{L}), \mathrm{Ca}^{2+}(8.4-9.8 \mathrm{mg} / \mathrm{L})$ and $\mathrm{K}^{+}$sub-class $(6.8-63 \mathrm{mg} / \mathrm{L})$. This justified that, not any measured parameter $\left(\mathrm{Cl}^{-}, \mathrm{Na}^{+}, \mathrm{Ca}^{2+}, \mathrm{Mg}^{2+}\right.$ or $\left.\mathrm{K}^{+}\right)$should contribute with its high class value to associate in the high value of EC. However, this assured that the zoning of EC high value was formed from the composition of all measured variables. Hence, the weight of each variable specifies its influential effect on the dependent variable. The association weight of every class within a single variable (assessed based on Equation (3)) was then cross processed in order to produce the PR for the entire variables. Table 6 represented the calculated PR given as the difference between the maximum relative frequencies and their corresponding minimum RF, divided by the least minimum RF of the whole variables.

Referring to the pre-calculated statistical correlation (Table 3) and comparing the results shown in Table 6, it was noticed that neither $\mathrm{Cl}^{-}$(correlation $R^{2}$ of $63 \%$ ), $\mathrm{K}^{+}$(correlation $R^{2}$ of $53 \%$ ) nor $\mathrm{Ca}^{2+}$ (correlation $R^{2}$ of $51 \%$ ) have been the most influencing variables when associated spatially with the moderately-salinewater class points. Instead, $\mathrm{Na}^{+}$has shown the higher percentage $(\mathrm{PR}=4.22)$ of areas that associated with $\mathrm{EC}$, followed by $\mathrm{Cl}^{-}, \mathrm{Mg}^{2+}$, $\mathrm{K}^{+}$and finally $\mathrm{Ca}^{2+}$. This statement indicated that the spatial correlation process took the individual weight into account along with the spatial extent of each variable when computing the association percentages. On the other hand, the statistical correlation has only considered correlating the measured values.

Table 6 Generation of prediction rate (PR) for the measured variables

\begin{tabular}{cccccc}
\hline Factor & Min. RF & Max. RF & [Max.-Min] & [Max.-Min]_min & PR \\
\hline $\mathrm{Cl}$ & 0.21 & 0.40 & 0.19 & & 3.21 \\
$\mathrm{Na}$ & 0.17 & 0.43 & 0.25 & & 4.22 \\
$\mathrm{Mg}$ & 0.26 & 0.41 & 0.14 & 0.06 & 2.38 \\
$\mathrm{Ca}$ & 0.31 & 0.37 & 0.06 & & 1.03 \\
$\mathrm{~K}$ & 0.43 & 0.57 & 0.14 & & 2.29 \\
\hline
\end{tabular}

In order to support the prediction ratios that acquired from the frequency ratio method, a pairwise comparison (PW) was additionally conducted making use of the spatially calculated PR's for the same variables and the same EC threshold wells. Table 7 showed the cross-process of PW for the evaluation of the resultant PR.

Table 7 The analysis of PW for PR evaluation

\begin{tabular}{|c|c|c|c|c|c|c|c|}
\hline \multicolumn{8}{|c|}{ Ratio calculation } \\
\hline PR & & 3.21 & 4.22 & 2.38 & 1.03 & \multicolumn{2}{|c|}{2.29} \\
\hline & Predictors & $\mathrm{Cl}$ & $\mathrm{Na}$ & $\mathrm{Mg}$ & $\mathrm{Ca}$ & \multicolumn{2}{|c|}{$\mathrm{K}$} \\
\hline 3.21 & $\mathrm{Cl}$ & 1.00 & 0.76 & 1.35 & 3.11 & \multicolumn{2}{|c|}{1.40} \\
\hline 4.22 & $\mathrm{Na}$ & 1.31 & 1.00 & 1.77 & 4.08 & \multicolumn{2}{|c|}{1.84} \\
\hline 2.38 & $\mathrm{Mg}$ & 0.74 & 0.56 & 1.00 & 2.30 & \multicolumn{2}{|c|}{1.04} \\
\hline 1.03 & $\mathrm{Ca}$ & 0.32 & 0.24 & 0.43 & 1.00 & \multicolumn{2}{|c|}{0.45} \\
\hline 2.29 & $\mathrm{~K}$ & 0.72 & 0.54 & 0.97 & 2.22 & \multicolumn{2}{|c|}{1.00} \\
\hline & Sum & 4.09 & 3.11 & 5.52 & 12.71 & \multicolumn{2}{|c|}{5.72} \\
\hline \multicolumn{8}{|c|}{ Weight calculation } \\
\hline PR & & 3.21 & 4.22 & 2.38 & 1.03 & 2.29 & \multirow{2}{*}{ PW } \\
\hline & Predictors & $\mathrm{Cl}$ & $\mathrm{Na}$ & $\mathrm{Mg}$ & $\mathrm{Ca}$ & $\mathrm{K}$ & \\
\hline 3.21 & $\mathrm{Cl}$ & 0.24 & 0.24 & 0.24 & 0.24 & 0.24 & 1.22 \\
\hline 4.22 & $\mathrm{Na}$ & 0.32 & 0.32 & 0.32 & 0.32 & 0.32 & 1.61 \\
\hline 2.38 & $\mathrm{Mg}$ & 0.18 & 0.18 & 0.18 & 0.18 & 0.18 & 0.91 \\
\hline 1.03 & $\mathrm{Ca}$ & 0.08 & 0.08 & 0.08 & 0.08 & 0.08 & 0.39 \\
\hline \multirow[t]{2}{*}{2.29} & $\mathrm{~K}$ & 0.17 & 0.17 & 0.17 & 0.17 & 0.17 & 0.87 \\
\hline & Sum & 1.00 & 1.00 & 1.00 & 1.00 & 1.00 & \\
\hline
\end{tabular}

The resulting weighing of PW comparison has been produced in the form of the sum of every pairs of PR divided by the factor percentages regarding to the entire ratio. It could be remarked obviously from the two generated PR and PW scatter plot that both approaches molded identical weight of variables (Figure 3), with little lessening in the values of PW comparison. To sum up, the FR technique has shown the validity in analyzing the spatial distribution of the water measured variables, and in nominating the variable that had the higher association portion. It was statistically assessed that $\mathrm{Na}^{+}$, followed by $\mathrm{Cl}^{-}$, were the higher correlating parameters. In addition, the sub-class values of the independent variables which have associated with the region of EC threshold were also identified via the calculation of RF throughout the analysis. 


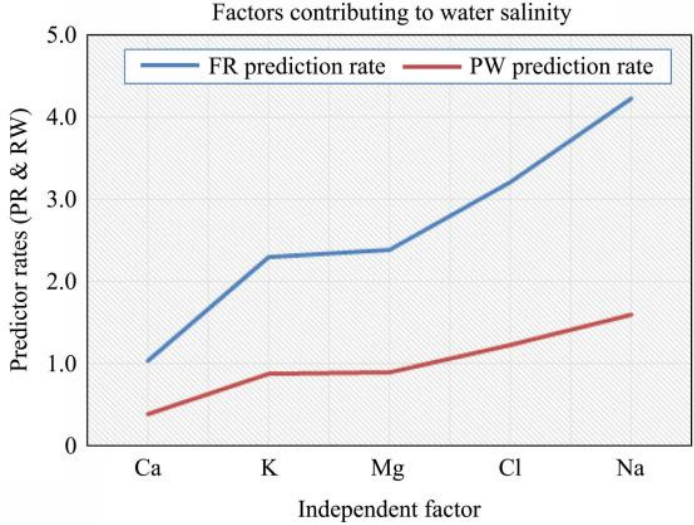

Figure 3 Scatter plot of the produced PR versus the PW comparison

Precisely, the resultant findings of FR have assured that although the statistical correlation (ANOVA) has presented $\mathrm{CL}^{-}$as the most influencing parameter in EC increase (high-high and low-low adjustment), FR has further depicted the nature of the spatial relationship between EC distribution and the added water chemicals. The obtained high spatial correlation between EC and $\mathrm{Na}^{+}$(high-high subclass each) revealed an overabundance of $\mathrm{Na}^{+}$ (unlike the ANOVA which showed higher $\mathrm{K}^{+}$and $\mathrm{Ca}^{2+}$ correlations) in the collected wells water, which might be due to probable sea water intrusion as the study area is located nearly $70 \mathrm{~km}$ apart from the coast of Arabian Gulf ${ }^{[19]}$. This further confirms the fact that $\mathrm{Na}^{+}$is the most abundant cation in sea water ${ }^{[31,32]}$. Additionally, in similar studies, $\mathrm{Hem}^{[33]}$ and Sultana ${ }^{[34]}$ stated that agricultural by-products could also be other sources of $\mathrm{Na}^{+}$content in groundwater.

On the other hand, studying and applying FR technique has proven the potential of spotting the associating parameter (spacewise), so that variable rate of chemicals in irrigation water can be applied accordingly. A clue to monitor water wells specification (i.e. rock formation differences, wells water depth. etc.) could also be provided through FR to address. Salinity tolerant crops can also be grown at the base of the assessed spatial distribution of the extracted water chemicals.

\section{Conclusions}

Water salinity represented by EC has been presented in this study as one of the parameters that has significantly participated in the decrease of irrigation water quality in the Al-Hassa oasis. The sharing factors in water EC quantification and distribution spacewise has been examined by applying the frequency ratio technique between some water measured chemical properties and salinity status (EC). Statistical correlation among the examined parameters and EC was conducted using SPSS and compared with the applied spatial correlation from the FR. Chlorine $\left(\mathrm{Cl}^{-}\right)$dosage in irrigation water was assessed to be the most important candidate for the increase of $\mathrm{EC}$, proved by a correlation $R^{2}$ of $63 \%$. However, the FR technique has shown the validity in analyzing the spatial distribution of the water measured variables, and in addition to nominating the variable that had the higher association portion. It was assessed that $\mathrm{Na}^{+}$, followed by $\mathrm{Cl}^{-}$, were the higher correlating parameters with prediction rates of 4.22 and 3.22 , respectively. In addition, the sub-class values of the independent variables which have associated with the region of EC threshold (EC $\geq 2.0 \mathrm{dS} / \mathrm{m}$ ) were also identified via the calculation of $\mathrm{RF}$ throughout the analysis.

\section{Acknowledgement}

This research was financially supported by the Deanship of Scientific Research at King Faisal University under Nasher Track (Grant No. 186240).

\section{[References]}

[1] Al Kharusi L, Assaha D, Al-Yahyai R, Yaish, M. Screening of date palm (Phoenix dactylifera L.) cultivars for salinity tolerance. Forests, 2017; 8(4): 136.

[2] Munns R. Comparative physiology of salt and water stress. Plant Cell Environ, 2002; 25: 239-250.

[3] Rhoades J D, Kandiah A, Mashali A M. The use of saline waters for crop production FAO irrigation and drainage paper FAO, Rome, No. 48, 1992.

[4] Marschner H. Mineral Nutrition of Higher Plants. $2^{\text {nd }}$ ed. London: Academic Press, 1995; ISBN: 9780124735439.

[5] Gale J, Zeroni M. The cost of plant of different strategies of adaptation to stress and the alleviation of stress by increasing assimilation. Plant Soil, 1985; 89: 57-67.

[6] Subbarao G V, Johansen C. Strategies and scope for improving salinity tolerance in crop plants. In: Pessarakli, M. Handbook of Plant and Crop Stress, CRC Press, Florida, USA, 3rd Ed, 2010; pp.1069-1087.

[7] Francois E F, Maas E V. Crop response and management of salt-affected soils. In: Pessarakli M. Handbook of Plant and Crop Stress. CRC Press, Florida, USA, 3rd Ed, 2010; pp.169-201.

[8] Karim F M, Dakheel A J. Salt-tolerant Plants of the United Arab Emirates. International Center for Biosaline Agriculture (ICBA), Dubai, UAE, 2006.

[9] Maathuis F J. The role of monovalent cation transporters in plant responses to salinity. Journal of Experimental Botany, 2006; 57(5): 1137-1147.

[10] Guzetti F, Carrara A, Cardinali M, Reichenbach P. Landslide hazard evaluation: a review of current techniques and their application in a multi-scale study, central Italy. Geomorphology, 1999; 31: 181-216.

[11] Aleotti P, Chowdhury R. Landslide hazard assessment: summary review and new perspectives. Bull Eng Geol Environ, 1999; 58: 21-44.

[12] Kanungo D P, Arora M K, Sarkar S, Gupta R P. Landslide Susceptibility Zonation (LSZ) Mapping - A Review. J South Asia Dis Stu., 2009; 2 : 81-105.

[13] Pardeshi D S, Autade E S, Pardeshi S S. Landslide hazard assessment: Recent trends and techniques. SpringerPlus, 2013; 2(1):523.

[14] Lee S. Application and verification of fuzzy algebraic operators to landslide susceptibility mapping. Environmental Geology, 2007; 52(4): 615-623.

[15] Pradhan B. Landslide susceptibility mapping of a catchment area using frequency ratio, fuzzy logic and multivariate logistic regression approaches. Journal of the Indian Society of Remote Sensing, 2010; 38(2): 301-320.

[16] Lepore C, Kamal S A, Shanahan P, Bars R L. Rainfall-induced landslide susceptibility zonation of Puerto Rico. Environmental Earth Sciences, 2012; 66(6): 1667-1681.

[17] Mohammady M, Pourghasemi H R, Pradhan B. Landslide susceptibility mapping at Golestan Province, Iran: a comparison between frequency ratio, Dempster-Shafer, and weights-of-evidence models. Journal of Asian Earth Sciences, 2012; 61: 221-236.

[18] Suzen M L, Vedat D A. A comparison of the GIS based landslide susceptibility assessment methods: multivariate versus bivariate. Environmental Geology, 2004; 45(5): 665-679.

[19] Al-Naeem A A. Evaluation of groundwater of Al-Hassa oasis, eastern region Saudi Arabia. Res. J. Environ. Sci. 2011; 5: 624-642.

[20] Al Tokhais A S, Rausch R. In The Hydrogeology of Al Hassa Springs. In Proceedings the 3rdInternational Conference on Water Resources and Arid Environments and the 1 Arab Water Forum, st Riyadh, Saudi Arabia, November 16-19, 2008; pp.16-19.

[21] Al-Sayari S, Zott J G. Quaternary period in Saudi Arabia. Springer-Verlag (Edited) Wien, New York, 1978.

[22] Al-Jabr M A. Agriculture in Al-Hassa oasis, Saudi Arabia: a review of development. Thesis, the Faculty of Social Sciences, University of Durham, UK, 1984.

[23] Wakuti. Studies for the project of improving irrigation and drainage in the region of al-Hassa, Saudi Arabia. Soil Study, Siegen, West Germany, 1964; 4, pp 2.

[24] Salih A. Classification and mapping of land cover types and attributes in 
Al-Ahsaa Oasis, Eastern Region, Saudi Arabia using Landsat-7 data. J. Remote Sensing \& GIS, 2018; $7: 228$.

[25] Althuwaynee O F, Pradhan B, Park H J, Lee J H. A novel ensemble bivariate statistical evidential belief function with knowledge-based analytical hierarchy process and multivariate statistical logistic regression for landslide susceptibility mapping. Catena, 2014; 114: 21-36.

[26] Peinado-Guevara H, Green-Ruíz C, Herrera-Barrientos J, Escolero-Fuentes $\mathrm{O}$, Delgado-Rodríguez O, Belmonte-Jiménez $\mathrm{S}$, et al. Relationship between chloride concentration and electrical conductivity in groundwater and its estimation from vertical electrical soundings (VESs) in Guasave, Sinaloa, Mexico. Ciencia e Investigación Agrarian, 2012; 39(1): 229-239

[27] Marion G M, Babcock K L. The solubilities of carbonates and phosphates in calcareous soil suspensions. Soil Science Society of America Journal, 1977; 41(4): 724-728.

[28] Hajrasuliha S, Cassel D K, Rezainejad Y. Estimation of chloride ion concentration in saline soils from measurement of electical conductivity of saturated soil extracts. Geoderma, 1991; 49: 117-127.

[29] Ursin A, Gimmi N T, Fluhler H. Combined effects of heterogeneity, anisotropy, and saturation on steady state flow and transport: A laboratory sand tank experiment. J. Water Resour. Res., 2001; 37(2): 201-208.

[30] Volkers Jr R E, Zhang Q, Lockington D A. Numerical modeling of contaminant transport in coastal aquifer Mathematics and Computers in Simulating, 2002; 59: 35-44.

[31] Brass G W, Turekian K K. Strontium distribution in GEOSECS oceanic profiles. Earth Planet. Sci. Lett., 1974; 16: 117-121.

[32] Brewer P G, Bradshaw A. The effect of the non-ideal composition of seawater on salinity and density. J. Mar. Res., 1975; 33: 157-175.

[33] Hem J D. Study and interpretation of the chemical characteristics of natural water. USGS WSP, $3^{\text {rd }}$ ed. Washington DC, 1989; 2254: 1-263.

[34] Sultana S. Hydrogeochemistry of the lower Dupi Tila Aquifer in Dhaka City, Bangladesh. TRITA-LWR Degree Project, 2009; 35: 1-42. 